Article

\title{
Evaluation of the Stability and Suitable Scale of an Oasis Irrigation District in Northwest China
}

\author{
Xifeng Zhang ${ }^{1}$, Yifan Zhang ${ }^{2}$, Jinghui Qi $^{3}$ and Qiang Wang ${ }^{4, *}$ \\ 1 College of Geography and Environment Science, Northwest Normal University, Lanzhou 730070, China; \\ zhangxifeng@nwnu.edu.cn \\ 2 Hubei Agricultural Planning and Design Institute, Wuhan 430070, China; fan970412vip@163.com \\ 3 School of Civil Engineering and Architecture, Zhengzhou University of Aeronautics, \\ Zhengzhou 450000, China; qijh2018@zua.edu.cn \\ 4 Northwest Institute of Eco-Environment and Resources, Chinese Academy of Science, \\ Lanzhou 730000, China \\ * Correspondence: wangqiang@llas.ac.cn; Tel.: +86-0931-8277-791
}

Received: 28 August 2020; Accepted: 5 October 2020; Published: 13 October 2020

check for updates

\begin{abstract}
Oases support human activities in arid and semiarid regions, and their stability is important for regional sustainable development and water resource management. Water consumption is the major factor affecting the stability of oases. On the basis of remote sensing images, evaporation and socioeconomic data, this study first evaluates the stability of the Dunhuang Oasis against the expansion of an oasis irrigation district and planting structure changes from 1987 to 2015. Next, it calculates a suitable area of the oasis irrigation district using water-energy balance theory. The results are as follows: (1) During the 1987-2015 period, with the expansion in the oasis irrigation area, the planting structure underwent a marked transformation from food crops to cash crops to orchards. Water consumption pattern likewise changed considerably. (2) The stability of the Dunhuang Oasis continued to weaken from 0.54 in 1987 until it reached a dangerously unstable level of 0.17 in 2010. With the implementation of water-saving measures and a water-transfer project, the stability of the Dunhuang Oasis irrigation district increased to a metastable level of 0.22 in 2015 . (3) Setting the stability are 0.5 of a stable level and 0.75 of an extremely stable level, and the oasis irrigation district should be impractical and reduced by 168 and $241 \mathrm{~km}^{2}$ to attain a suitable oasis ecosystem scale. Hence, at present, the water-transfer project is the most practical way to increase allocated water resource to the oasis irrigation district for improving its stability.
\end{abstract}

Keywords: oasis irrigation district; stability evaluation; suitable scale

\section{Introduction}

The mountain-oasis-desert unit is the main topographic feature of inland river watersheds in China [1]. For watersheds in this arid region, water from melted snow and glacier in the mountain flows through an oasis similar to a water tower, thereby providing fresh water to people and nature before disappearing into the desert. Through this morphotectonic pattern, as an important landscape, oases support human activities and economic development in arid regions [2] but are generally water deficient [3]. Its stability is directly related to the sustainable development of regional economy and ecological security [2].

In recent decades, the expansion of the irrigation district, population growth, and economic development in the middle-stream oasis of the inland river basin has considerably modified hydrological cycles and reduced surface runoffs to downstream reaches. Consequently, this situation has led to dried-up rivers, reduced outflows to terminal lakes, and the deterioration of the ecosystem in 
downstream areas [4-7]. These effects have manifested in dried-up inland lakes, such as the Aral Sea in Central Asia [8,9], Lake Urmia in Iran [10,11], and the Shiyang River in Northwestern China [12]. Thus, assessing whether an oasis is stable under the present development pattern is important in the pursuit of sustainable development. Moreover, evaluating a suitable oasis scale is crucial to the government development plan.

Several studies on stability evaluation and suitable oasis scales have focused on the Endorheic Basin in Northwest of China, specifically, the Keriya River Basin [13], the Manas River Basin [2], the Tarim River Basin [14], the Weigan River [15], and the Heihe River Basin [16]. Research methods in stability evaluation and suitable scales have continuously progressed owing to the rapid development of ecological hydrology. In the past, suitable oasis cropland areas were calculated by establishing a regression equation using the total amount of runoff water resources and the cropland area of the oasis [17]. Wang et al. [18] applied contrastive analysis to different oasis landscapes and their homologous water-energy balance relationship and proposed the concept of the "green degree" to assess stability evaluation and suitable oasis scales. In addition, a suitable farmland scale model had been established from the perspective of crop water footprint and water resources available in an oasis city [19]. Recently, Hao et al. [16] developed an approach for calculating oasis and cultivated land scales by combining water-energy balance and wind-sand dynamic theories with ecological health assessments in the Heihe River Basin.

Agricultural irrigation consumes the largest proportion of the water supply of an oasis, and the suitability of a cropland scale can directly affect the stability of an oasis. Previous research on stability evaluation and suitable oasis scales has generally neglected the impact of changes in planting structure and agricultural water consumption. Additionally, no relevant studies have been conducted on the Shule River Basin, which is adjacent to the Heihe River Basin. The Dunhuang Oasis, which is the study area of this research, is located west of the Shule River Basin and an important region along the Silk Road.

Similar to the case of the middle reaches of the Heihe River Basin, the Dunhuang Oasis also has a sharp contradiction of the water resource issue between the economy and the ecosystem. In the past decade, planting structures constantly changed with the expansion in oasis irrigation areas. Moreover, water exploitation and utilization rates reached nearly $100 \%$ in the oasis, in which agricultural water consumption accounted for nearly $90 \%$ of total available resources [20]. Hence, natural oasis ecosystems are unable to receive necessary water resources. Dunhuang City has proposed a water resource plan, namely, the "Comprehensive Planning of the Rational Use of Water Resource and Protection of Ecosystem Services in the Dunhuang Basin" [21] to improve the ecological environment of its natural oasis. The main purpose of this plan is to allocate large amounts of water resources to the natural oasis in the lower reaches of the Dunhuang Basin and leave only a limited amount of water for the irrigation district of the Dunhuang Oasis.

The objective of this study is to propose a novel research idea to evaluate the stability of the oasis and calculate the suitable oasis scale by combining water-energy balance with altered planting structures. First, this study evaluates stability during the long-term expansion process of the Dunhuang Oasis from 1987 to 2015. Next, it calculates a suitable oasis scale to a certain stability degree. Finally, it discusses to what extent the current water plan can improve the stability of the oasis and provides a scientific reference for the sustainable development of the oasis.

\section{Materials and Methods}

\subsection{Study Area}

The Dunhuang Oasis irrigation district is located east of Dunhuang City $\left(92^{\circ} 13^{\prime}-95^{\circ} 30^{\prime} \mathrm{N}\right.$, $39^{\circ} 40^{\prime}-41^{\circ} 40^{\prime}$ E) in Northwest China, with a total area less than $5 \%$ of that of the entire city (Figure 1). The Dunhuang Oasis irrigation district lies between the Mingsha Mountain (Echoing-sand Mountain) and the Sanwei Mountain in the southeast and the Mazong Mountain in the north and spreads into the 
Gobi Desert in the west, thereby earning the name the "Gobi Desert Oasis". The world famous Mogao Grottoes are located southwest of the Dunhuang Oasis. The elevation of the oasis ranges from 800 to $1500 \mathrm{~m}$ and is high in the south and low in the north. The oasis experiences the strong sunshine with the annual solar radiation reaches to $6418.4 \mathrm{MJ} / \mathrm{m}^{2}$, and mean maximum and minimum temperatures are $-28.6-43.6{ }^{\circ} \mathrm{C}$. The oasis also experiences high evaporation, with the annual potential evaporation reaches $2486.0 \mathrm{~mm}$, but the annual precipitation is only $39.2 \mathrm{~mm}$. The Danghe River, which originates from the Qilian Mountain, provides the water resources for the oasis, and the Danghe River alluvial fan developed the oasis. The oasis consists mainly of gray brown desert, alkali saline, and irrigation desert soil (China soil science database, http://vdb3.soil.csdb.cn). According to the Dunhuang City National Economic Statistics Yearbook (1987-2015), spring wheat, melon, cotton, and grapes are the main crops planted in this area [22].

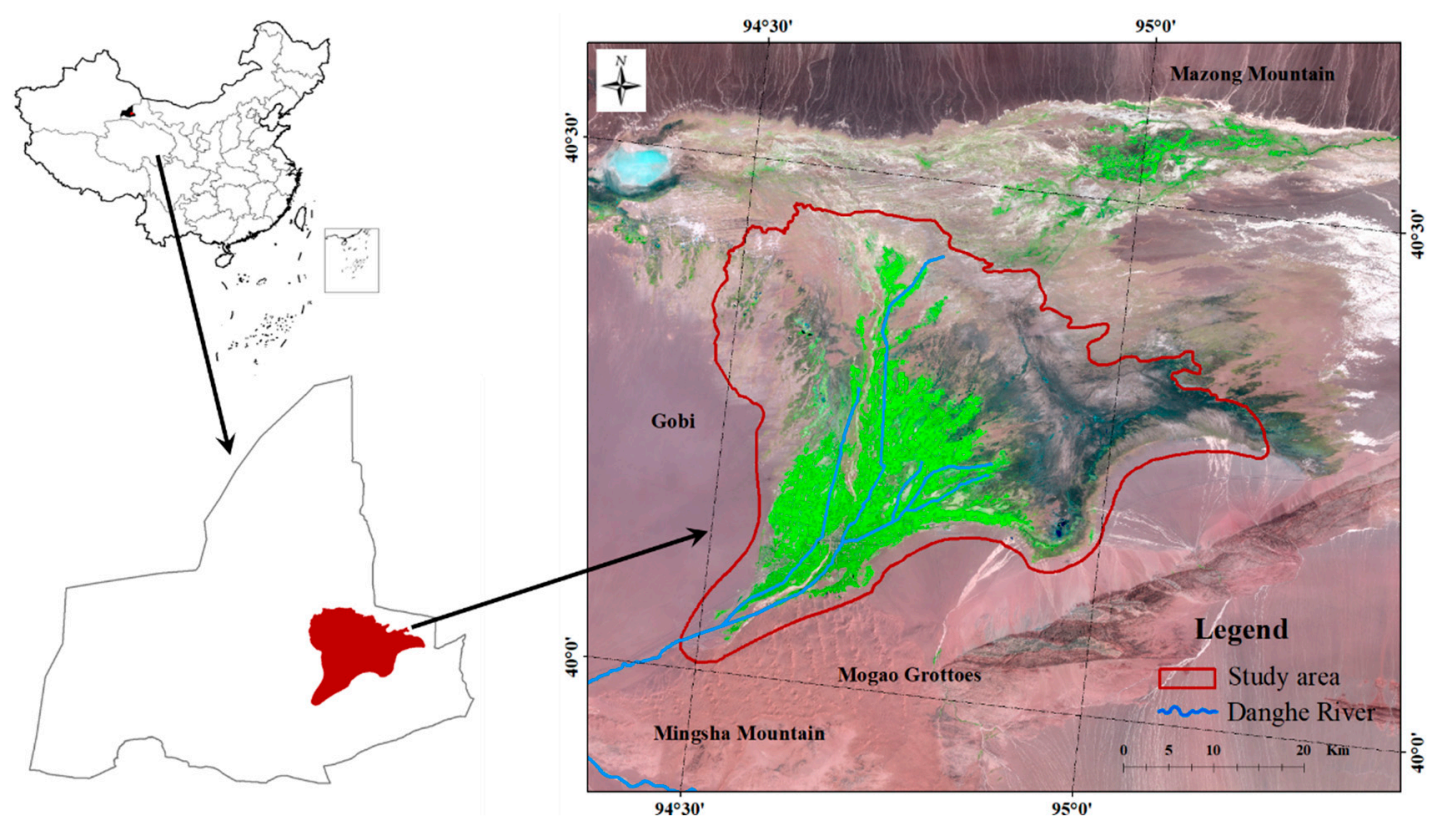

Figure 1. Study area derived by Landsat TM imagery (Bands 5-4-3).

\subsection{Remote Sensing Image Data Processing}

The high-quality remote images with a $30 \mathrm{~m}$ spatial resolution from Landsat TM (Thematic Mapper) were taken in low cloud covers during high biomass season, and all mage data were acquired from http://glovis.usgs.gov/ and http://www.radi.ac.cn/. We selected 1987, 1990, 1996, 2001, 2007, 2010, and 2015 to identify the actual irrigation district of the oasis using the software of ERDAS 9.1 and ArcGIS 10.3. Based on a 1:250,000 topographic map of the Dunhuang Oasis, all images were processed under the common universal transverse mercator coordinate system. A total of 50 uniformly distributed ground control points (e.g., roads and rivers) were used for geometric correction and georeferencing, and we used the quadratic polynomial transformation and nearest-neighbor resampling methods to identify ground control points in image-to-map rectification, the root mean square error of the geometrical rectification was less than one pixel. When the images were all ready, we divided the land use types into eight classes according to visual interpretation, namely, cropland, water, high-density grassland, medium-density grassland, low-density grassland, shrub land, urban construction land, and barren land. For verifying the result of visual interpretation, the field investigation points and corresponding interpretation results were compared, and the overall interpretation accuracy of land use classification in the 1987, 1990, 1996, 2001, 2007, 2010, and 2015 images was 80.91\%, 84.96\%, 79.85\%, $79.69 \%, 84.98 \%, 85.79 \%$, and $89.45 \%$, respectively, which met the minimum accuracy requirement of $70 \%$ [23]. In this study, we used only the results of the cropland in the interpretation, as the scale of the 
oasis was mainly affected by the changes in the cropland. On the basis of the interpreted cropland data, we calculated the actual crop areas of crop food, cash food, and orchards by multiplying the crop food, cash food, and orchard area ratios in the Dunhuang City statistical yearbook [22] to determine the water consumption of each crop and orchard.

\subsection{Water Consumption Data Analyses}

In this study, water consumption denoted crop, domestic, and industrial water consumption.

\subsubsection{Crop Water Consumption}

The Food and Agricultural Organization (FAO)-Penman-Monteith methods were used to estimate reference crop evapotranspiration $\left(\mathrm{ET}_{0}\right)$, and multiplying by the crop coefficient $(\mathrm{Kc})$ can get actual evapotranspiration (ET) as crop water consumption [24]:

$$
\mathrm{ET}_{0}=\frac{0.408 \Delta\left(\mathrm{R}_{\mathrm{n}}-\mathrm{G}\right)+\gamma \frac{900}{\mathrm{~T}+273} \mathrm{U}_{2\left(\mathrm{e}_{\mathrm{s}}-\mathrm{e}_{\mathrm{a}}\right)}}{\Delta+\gamma\left(1+0.34 \mathrm{U}_{2}\right)}
$$

$\mathrm{R}_{\mathrm{n}}$ is the net radiation at the canopy surface $\left(\mathrm{MJ} / \mathrm{m}^{2}\right.$. day);

$\mathrm{G}$ is the soil heat flux density $\left(\mathrm{MJ} / \mathrm{m}^{2}\right.$. day);

$\mathrm{T}$ is the mean daily air temperature at $2 \mathrm{~m}$ above the ground $\left({ }^{\circ} \mathrm{C}\right)$;

$\mathrm{U}_{2}$ is the wind speed at $2 \mathrm{~m}$ above the ground $(\mathrm{m} / \mathrm{s})$;

$\mathrm{e}_{\mathrm{s}}$ is the saturation vapor pressure $(\mathrm{kPa})$;

$\mathrm{e}_{\mathrm{a}}$ is the actual vapor pressure $(\mathrm{kPa})$;

$e_{s}-e_{a}$ is the saturation vapor pressure deficit $(\mathrm{kPa})$;

$\Delta$ is the slope of the vapor pressure temperature relationship $\left(\mathrm{kPa} /{ }^{\circ} \mathrm{C}\right)$;

$\gamma$ is the psychometric constant $\left(\mathrm{kPa} /{ }^{\circ} \mathrm{C}\right)$.

Based on the above principle, $\mathrm{ET}_{0}$ is computed using the CropWat 8.0 [25] tool after the monthly averages of minimum temperature, maximum temperature, humidity, wind speed, and sunshine hours are inputted.

The values of Kc vary with the crop development stages, and values of monthly Kc were adopted from FAO-56 [24] for spring wheat, cotton and grape. Adjustments to Kc mid in climates where $\mathrm{RH}_{\text {min }}$ differs from $45 \%$ or wher $U_{2}$ is larger or smaller than $2.0 \mathrm{~m} / \mathrm{s}$, were made by following the guidelines of Allen et al. [24]:

$$
\begin{aligned}
& \mathrm{K}_{\mathrm{cmid}}=\mathrm{K}_{\mathrm{cmid}(\mathrm{Tab})}+\left[0.04\left(\mathrm{U}_{2}-2\right)-0.004\left(\mathrm{RH}_{\min }-45\right)\right]\left(\frac{\mathrm{h}}{3}\right)^{0.3} \\
& \mathrm{~K}_{\mathrm{cend}}=\mathrm{K}_{\mathrm{cend}(\mathrm{Tab})}+\left[0.04\left(\mathrm{U}_{2}-2\right)-0.004\left(\mathrm{RH}_{\min }-45\right)\right]\left(\frac{\mathrm{h}}{3}\right)^{0.3}
\end{aligned}
$$

$\mathrm{K}_{\mathrm{cmid}(\mathrm{Tab})}$ is the tabulated Kc values in the mid-seasonof Table VI-12 of Allen et al. [24];

$\mathrm{K}_{\mathrm{cend}(\mathrm{Tab})}$ is the tabulated $\mathrm{Kc}$ values in the late-season of Table VI-12 of Allen et al. [24];

$U_{2}$ is wind speed at $2 \mathrm{~m}$ height over grass, the range is $1 \mathrm{~m} / \mathrm{s} \leq U_{2} \leq 6 \mathrm{~m} \mathrm{~m} / \mathrm{s}$;

$\mathrm{RH}_{\text {min }}$ is daily minimum relative humidity, the range is $20 \% \leq \mathrm{RH}_{\min } \leq 80 \%$;

$\mathrm{H}$ is mean plant height, the range is $0.1 \mathrm{~m} \leq \mathrm{h} \leq 10 \mathrm{~m}$.

This research considered the water consumption of vines. Figure 2 shows the adjusted $\mathrm{K}_{\mathrm{C}}$ of wheat, cotton and grape. Compared with wheat and cotton, the $\mathrm{K}_{\mathrm{C}}$ of grape is more complicated, and the values of the germination, growing season with shoots, flowering, and berry growing periods as well as berry and tendril maturation were $0.80,1.09,1.13,1.07,1.03$, and 0.82 , respectively. 

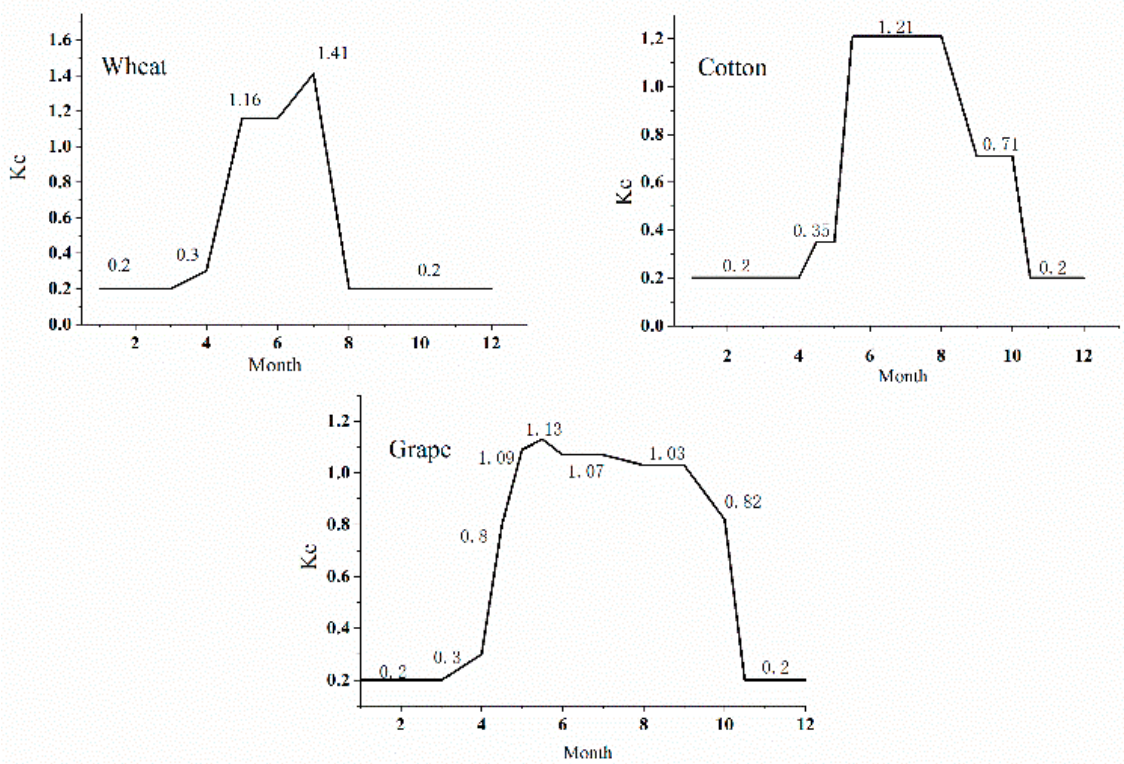

Figure 2. Crop evapotranspiration coefficients.

Actual ET rates of food crops and cash crops are estimated by Allen et al. [24]

$$
\mathrm{ET}=\mathrm{ET}_{0} \times \mathrm{K}_{\mathrm{C}}
$$

\subsubsection{Domestic Water Consumption}

Domestic water consumption represented the water consumption of urban and rural populations, tourists, and livestock, which was positively correlated with living standards. It is defined as follows:

$$
\mathrm{D}=\left(\mathrm{P}_{1} \times \mathrm{C}_{1}+\mathrm{P}_{2} \times \mathrm{C}_{2}+\mathrm{P}_{3} \times \mathrm{C}_{3}+\mathrm{P}_{4} \times \mathrm{C}_{4}\right) \times 365 \times 10^{-8}
$$

$\mathrm{D}$ is the total domestic water consumption $\left(10^{8} \mathrm{~m}^{3}\right)$;

$\mathrm{P}_{1}$ is the amount urban population $\left(10^{8} \mathrm{~m}^{3}\right)$;

$\mathrm{P}_{2}$ is the amount rural population $\left(10^{8} \mathrm{~m}^{3}\right)$;

$\mathrm{P}_{3}$ is the amount tourists population $\left(10^{8} \mathrm{~m}^{3}\right)$;

$\mathrm{P}_{4}$ is the amount livestock number $\left(10^{8} \mathrm{~m}^{3}\right.$, sheep unit);

$\mathrm{C}_{1}$ is the average per capital water use coefficient of urban (L/day);

$\mathrm{C}_{2}$ is the average per capital water use coefficient of rural (L/day);

$\mathrm{C}_{3}$ is the average per capital water use coefficient of tourist (L/day);

$\mathrm{C}_{4}$ is the average per capital water use coefficient of livestock (L/day);

The values for $\mathrm{C}_{1}, \mathrm{C}_{2}, \mathrm{C}_{3}$ and $\mathrm{C}_{4}$ (Table 1 ) are obtained from the literature for the four periods with different living standards: 1987-1990, 1991-2000, 2001-2007, and 2008-2015 [26].

Table 1. Water use coefficient.

\begin{tabular}{cccccc}
\hline Item & & Coefficient & Unit \\
\hline & $1987-1990$ & $1991-2000$ & $2001-2007$ & 2008-2015 & \\
\hline Urban resident water-use coefficient $\left(C_{1}\right)$ & 80 & 95 & 110 & 120 & L/day \\
Rural resident water-use coefficient $\left(C_{2}\right)$ & 25 & 45 & 60 & 80 & L/day \\
Tourist water-use coefficient $\left(C_{3}\right)$ & 100 & 250 & 400 & 400 & L/day \\
Livestock water-use coefficient $\left(C_{4}\right)$ & 15 & 15 & 20 & 20 & L/day \\
Industrial water-use coefficient $\left(C_{5}\right)$ & 215 & 205 & 185 & 180 & $\mathrm{~m}^{3} / 10^{4} \mathrm{RMB}$ \\
\hline
\end{tabular}




\subsubsection{Industrial Water Consumption}

Industrial water consumption was affected by industrial output, technology, processes, and the amount of water used to create RMB 10,000 (Chinese currency) worth of industrial output. It is defined as follows:

$$
\mathrm{P}=\text { Indo } \times \mathrm{C}_{5} \times 10^{-8}
$$

$\mathrm{P}$ is the industry water use $\left(10^{8} \mathrm{~m}^{3}\right)$;

Indo is the industrial output (RMB);

$C_{5}$ is the amount of water used to create $10,000 \mathrm{RMB}$ worth of industrial output ( $\left.\mathrm{m}^{3} / 10^{4} \mathrm{RMB}\right)$.

The value for $\mathrm{C}_{5}$ (Table 1) was also determined separately for the four periods with different living standards for the period of 1987-1990, 1991-2000, 2001-2007, and 2008-2015, respectively [26].

\subsection{Oasis Stability and Suitable Oasis Scale Model}

In this study, a stability index $\left(\mathrm{H}_{0}\right)$, which is based on the theory of ecological water-energy balance, was used to estimate the stability degree of the oasis under certain water resource conditions [18]. $\mathrm{H}_{0}$ is the relative equilibrium analysis between water and energy conditions of the oasis, which can not only reflect ecological evolution and degradation from the internal perspective of the oasis but also the "green degree" or "stability degree" from the overall regional view point. The greater the $\mathrm{H}_{0}$, the less affected the water stress and the higher the oasis stability, and vice versa. The formula is as follows:

$$
\mathrm{H}_{0}=\frac{\mathrm{W}_{1}-\mathrm{W}_{2}+\mathrm{P} \times \sum \mathrm{A}_{\mathrm{i}}}{\mathrm{ET}_{0} \times \sum \mathrm{A}_{\mathrm{i}}}
$$

where $A_{i}$ is the area of the land type ( $I=$ food crops, cash crops, and grapes; $\left.\mathrm{km}^{2}\right), \mathrm{W}_{1}$ is the total available water volume of the river basin $\left(10^{8} \mathrm{~m}^{3}\right), \mathrm{W}_{2}$ is the annual average agricultural, industrial, and domestic water consumption, $\mathrm{ET}_{0}$ is the reference crop evapotranspiration, and $\mathrm{P}$ is the annual average precipitation. The $\mathrm{H}_{0}$ of the oasis was classified on the basis of the characteristics of the natural environment (Table 2).

Table 2. Classification of oasis stability.

\begin{tabular}{ccc}
\hline $\mathbf{H}_{\mathbf{0}}$ & Type & Evaluation of Exploration and Utilization \\
$>0.75$ & Extremely stable & Has potential \\
$0.50-0.75$ & Stable & Safeguarded; the oasis has limited developmental potential \\
$0.20-0.50$ & Metastable & Does not have developmental potential \\
$<0.20$ & Unstable & Reduced oasis scale \\
\hline
\end{tabular}

Based on the previous section, the calculation model of the suitable oasis scale (A) is

$$
\mathrm{A}=\frac{\mathrm{W}_{1}-\mathrm{W}_{2}}{\left(\mathrm{ET}_{0}-\mathrm{P}\right) \times \mathrm{k}_{\mathrm{p}} \times \mathrm{H}_{0}^{*}}
$$

where $\mathrm{k}_{\mathrm{p}}$ is the comprehensive coefficient of plants in the oasis, which includes planting crops, trees, and grass. $\mathrm{H}_{0}^{*}$ is used to estimate the suitable oasis scale.

\section{Results}

\subsection{Land Use/Land Cover Changes between 1987 and 2015}

Figures 3 and 4 show changes in land use/land cover between 1987 and 2015. From Figure 3, we can deduce that the cropland area exhibited an expanding pattern, and the interpretation results demonstrate the total cropland area in the oasis was $272.69,276.41,295.33,327.08,371.40,380.47$, and 
$389.41 \mathrm{~km}^{2}$ in $1987,1990,1996,2000,2007,2010$, and 2015 , respectively. In terms of the temporal characteristics of land use/land cover changes, incremental rates from 1996 to 2007 more than doubled from 1987 to 1996 and from 2007 to 2015 . With regard to spatial pattern, the cropland increased by $116.72 \mathrm{~km}^{2}$. Growth is mainly attributed to its transformation from a grassland and a barren land in the fringe of the oasis [27] and to the continuously expanding urban construction land within the oasis.
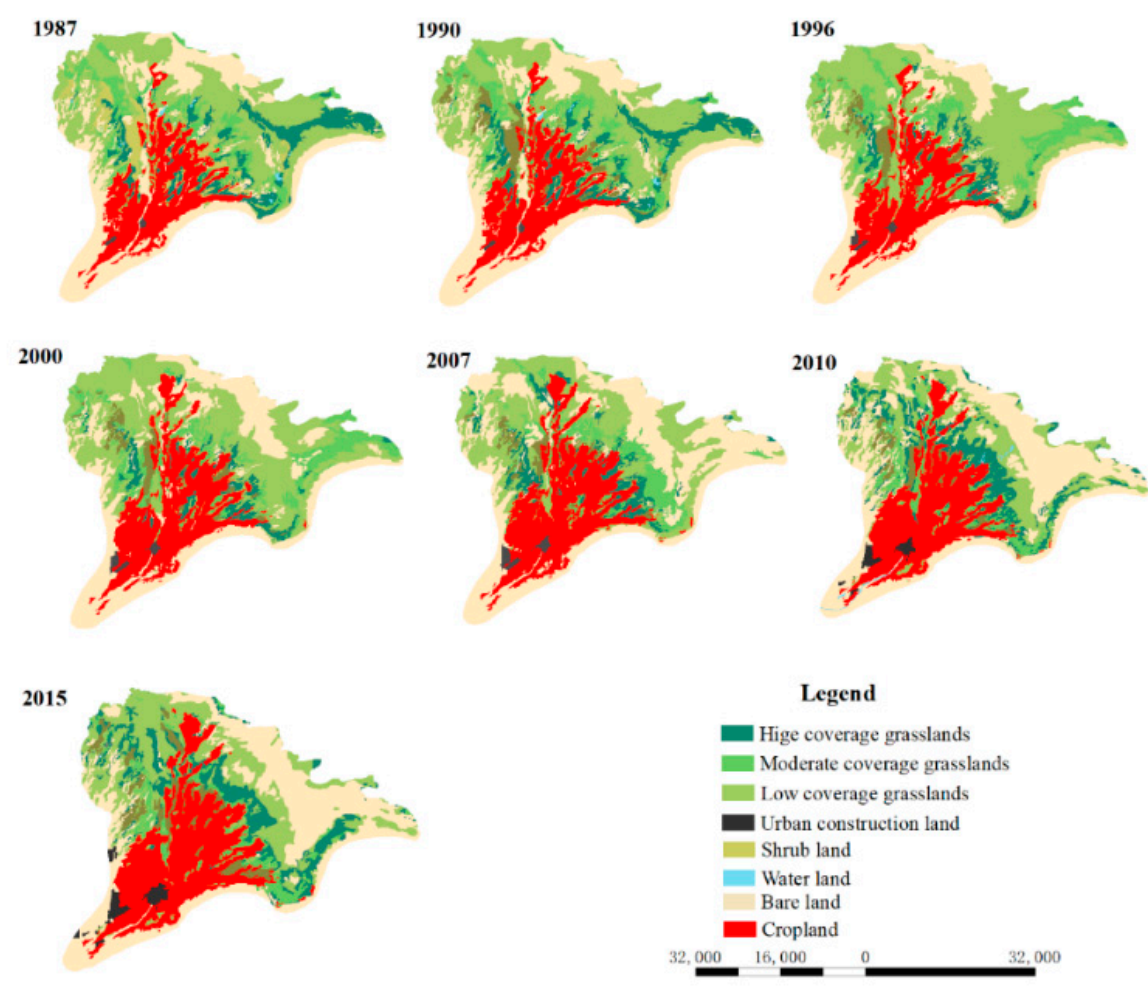

Figure 3. Land use/land cover spatial pattern from 1987 to 2015 in the Dunhuang Oasis.

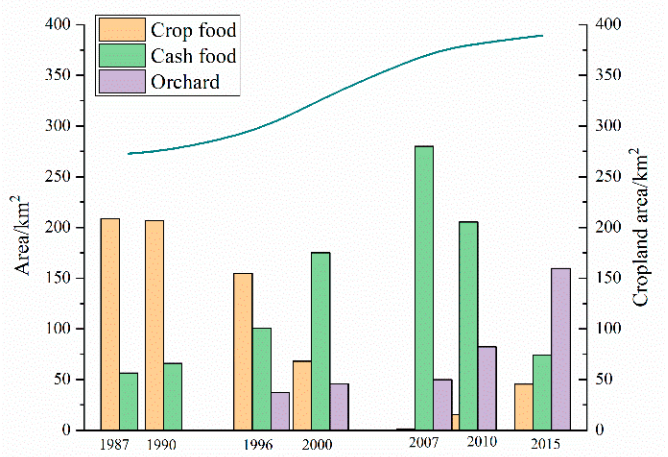

Figure 4. Planting structure changes in the Dunhuang Oasis.

The three different-colored bar charts in Figure 4 represent the crop areas of crop food, cash food, and orchards. The planting structure exhibited marked changes and even transformed during the 1987-2015 period. Specifically, (1) the crop food area decreased continuously from 1987 to 2007, and the crop food area in 2007 was only $1.61 \mathrm{~km}^{2}$, making it too small to display. Meanwhile, cotton was the main cash crop, which experienced a substantial increase owing to its high value. A distinct transformation in the food and cash crops from 1996 to 2000 can be observed, as the crop area of the cash crops gradually became larger than that of the food crops. In addition, the trial planting of grapes in the sandy soil region began in 1996. (2) In 2010, cotton areas gradually decreased, and grape orchards increasingly involved large-scale cultivation. 


\subsection{Water Consumption}

\subsubsection{Agricultural Water Consumption}

Agricultural water consumption comprises the core section of the suitability evaluation of the oasis. In the Dunhuang Oasis, agricultural water consumption includes food crops, cash crops, and orchards. From 1987 to 2015 , total water consumption increased initially from $2.293 \times 10^{8} \mathrm{~m}^{3}$ in 1987 to $3.513 \times 10^{8} \mathrm{~m}^{3}$ in 2007 , then decreased to $2.902 \times 10^{8} \mathrm{~m}^{3}$ in 2015 (Table 3). Listed individually in Table 3, food crop water consumption decreased sharply by $1.334 \times 10^{8} \mathrm{~m}^{3}$ from 1987 to 2015 . Meanwhile the water consumption of cash crops with high economic benefits progressively increased by $2.374 \times 10^{8} \mathrm{~m}^{3}$ from 1987 to 2007 then began to decrease to $2.207 \times 10^{8} \mathrm{~m}^{3}$ in 2010 and eventually decrease to a very low value of $0.774 \times 10^{8} \mathrm{~m}^{3}$ in 2015 . This trend in cash crop water consumption is closely related to that of grapes, which increased slowly before 2010 before rising rapidly.

Table 3. Agricultural water consumption in 1987-2015 $\left(10^{8} \mathrm{~m}^{3}\right)$.

\begin{tabular}{ccccc}
\hline Year & Food Crop & Cash Crop & Grape/Orchard & Sum \\
\hline 1987 & 1.727 & 0.566 & 0 & 2.293 \\
1990 & 1.754 & 0.668 & 0 & 2.422 \\
1996 & 1.300 & 0.984 & 0.389 & 2.673 \\
2000 & 0.585 & 1.780 & 0.489 & 2.854 \\
2007 & 0.015 & 2.940 & 0.558 & 3.513 \\
2010 & 0.139 & 2.207 & 0.915 & 3.261 \\
2015 & 0.393 & 0.774 & 1.735 & 2.902 \\
\hline
\end{tabular}

\subsubsection{Domestic and Industrial Water Consumption}

Domestic and industrial water consumption should not be neglected in the suitability evaluation of the oasis. During the 1987-2015 period, the total population of the Dunhuang Oasis increased from 108,373 to 142,558 , in which the rural population accounted for nearly $70 \%$ to $80 \%$. Rural livestock increased from 349,820 sheep units in 1987 to 486,816 in 2015. In addition, the number of tourists increased from less than 100,000 in 1987 to 6,603,914 in 2015. Furthermore, industrial output increased by $84.6 \times 10^{8} \mathrm{RMB}$ [22]. Thus, we can calculate overall domestic and industrial water consumption under increasing populations and the booming tourism industry. Table 4 shows that overall domestic and industrial water consumption rapidly increased from $0.038 \times 10^{8}$ to $0.219 \times 10^{8} \mathrm{~m}^{3}$. The percentage of domestic and industrial water consumption in overall water consumption is very small.

Table 4. Domestic and industrial water consumption in 1987-2015 $\left(10^{8} \mathrm{~m}^{3}\right)$.

\begin{tabular}{cccc}
\hline Year & Domestic & Industrial & Sum \\
\hline 1987 & 0.034 & 0.004 & 0.038 \\
1990 & 0.036 & 0.007 & 0.043 \\
1996 & 0.050 & 0.026 & 0.076 \\
2000 & 0.045 & 0.045 & 0.09 \\
2007 & 0.064 & 0.117 & 0.181 \\
2010 & 0.075 & 0.116 & 0.192 \\
2015 & 0.102 & 0.117 & 0.219 \\
\hline
\end{tabular}

\subsection{Oasis Stability Evaluation}

In this study, the total available water volume originates from the Danghe River; thus, we use its perennial mean runoff, that is, $4.13 \times 10^{8} \mathrm{~m}^{3}$, as $\mathrm{W}_{1}$. From the above data, total available water quantity for the oasis in 1987, 1990, 1996, 2000, 2007, 2010, and 2015 was $1.79 \times 10^{8}, 1.66 \times 10^{8}, 1.37 \times 10^{8}$, $1.78 \times 10^{8}, 0.43 \times 10^{8}, 0.67 \times 10^{8}$, and $1.00 \times 10^{8} \mathrm{~m}^{3}$, respectively. From the oasis stability evaluation, 
as shown in Equation (7), the $\mathrm{H}_{0}$ of the Dunhuang Oasis were $0.54,0.51,0.41,0.39,0.15,0.19$, and 0.22 from 1987 to 2015 (Table 5).

Table 5. Stability of Dunhuang Oasis.

\begin{tabular}{ccccc}
\hline Year & $\mathbf{P} /(\mathbf{m m})$ & $\mathbf{E T}_{\mathbf{0}} / \mathbf{( m m )}$ & $\left.\mathbf{W}_{\mathbf{1}}-\mathbf{W}_{\mathbf{2}} \mathbf{( \mathbf { 1 0 }} \mathbf{~ m}^{\mathbf{3}}\right)$ & $\mathbf{H}_{\mathbf{0}}$ \\
\hline 1987 & 43.80 & 1300 & 1.79 & 0.54 \\
1990 & 45.60 & 1279 & 1.66 & 0.51 \\
1996 & 40.20 & 1288 & 1.37 & 0.41 \\
2000 & 36.70 & 1357 & 1.78 & 0.39 \\
2007 & 87.40 & 1355 & 0.43 & 0.15 \\
2010 & 50.90 & 1322 & 0.67 & 0.17 \\
2015 & 31.40 & 1299 & 1.00 & 0.22 \\
\hline
\end{tabular}

\subsection{Suitable Oasis Irrigation District Scale}

We take 2015 as an example and use Equation (8) to derive a suitable oasis irrigation district scale. Crops and natural vegetation are considered as having a common effect on $\mathrm{kp}$, which is 0.72 [18], and the $\mathrm{H}_{0}^{*}$ is set as two values, namely, 0.5 for the stable level and 0.75 for the extremely stable level.

Table 6 shows that the suitable oasis irrigation district scale was smaller than the actual area in 2015. According to the water-energy balance model, the current oasis irrigation district scale should be reduced by 168 and $241 \mathrm{~km}^{2}$ to attain stable to extremely stable levels, respectively.

Table 6. Suitable oasis irrigation district scales $/ \mathrm{km}^{2}$.

\begin{tabular}{cccc}
\hline Year & $\mathbf{H}_{0}^{*} \mathbf{( 0 . 5 - 0 . 7 5 )}$ & Status Quo 2015 & Suitable Scale(A)/Km ${ }^{2}$ \\
\hline \multirow{2}{*}{2015} & 0.5 & 389 & 221 \\
& 0.75 & & 148 \\
\hline
\end{tabular}

\section{Discussion}

The planting structure exhibited two marked changes. The first planting structure change happens between crop food and cotton. Except for cotton's high value and cultivation suitability, the rapidly increasing cotton lands, which were mainly attributed to farmers, had autonomy in terms of land use activities since the early 1980s under China's economic reform policy. Against this background, farmers envisioned market economy ideas, and production activities were closely associated with market demands. In addition, the trial planting of grapes in the sandy soil region began in 1996. The second planting structure change happens between cotton and grape; this is because of successful grape trial experiments in the sandy soil region, and from then on, a large number of farmers began to install grape trellises in fields previously planted with cotton or wheat. Hence, the planting structure of the oasis changed once again.

Although the total cropland area increased by $18.01 \mathrm{~km}^{2}$ from 2007 to 2015, agricultural water consumption decreased by $0.611 \times 10^{8} \mathrm{~m}^{3}$. This result may be beneficial to the transformation of crop patterns and water-saving irrigation measures. Traditional field canal irrigation was the primary irrigation pattern used in the past, but, from the beginning of 2010, advanced water-saving irrigation models, such as micro, pipe, and greenhouse micro irrigation, were implemented in the entire oasis.

Table 5 shows that stability was in a stable level in 1987 and 1990 owing to low agricultural, domestic, and industrial water consumption. During this period, though each industry was gradually developing, stability was not extremely stable, which may have been due to limited water resources. Farmers' enthusiasm for production and cropland areas increased under reform and opening-up policies, but irrigation measures were difficult. At the same time, tourism in the Dunhuang Oasis began to flourish. When the national economy improved, the stability of the oasis fell to a metastable level from 1996 to 2000 and reached a dangerously unstable level from 2007 to 2010 . Water resource 
exploitation and utilization rates nearly reached $100 \%$ in the oasis, in which agricultural water consumption accounted for nearly $90 \%$ of overall available resources [27]. Serious ecological problems, such as accelerated desertification and salinization, shrunken terminal lake and declining groundwater level, accompany rapid economic development [27]. Water has become the primary restricting and bottleneck factor in the socioeconomic development of the Dunhuang Oasis.

In this case, a series of water resource plans was implemented to address this issue, in which the most important program "Comprehensive Planning of the Rational Use of Water Resource and Protection of Ecosystem Services in the Dunhuang Basin" was proposed. This program aims to reduce the croplands of state farms, implement agricultural water-saving measures, and carry out a water diversion project from the Sugan Lank Basin to the Danghe River. Approximately $0.835 \times 10^{8} \mathrm{~m}^{3}$ of water allocated from the water diversion project is intended for the improvement of the ecological environment, which plays a crucial role in alleviating the water crisis by increasing groundwater levels and recovering the vegetation in marginal areas of the oasis [20]. The system dynamic model simulated the agricultural water consumption under different scenarios in the Dunhuang Oasis and shows that the proportion of agricultural water consumption in overall water consumption can be reduced from $92.50 \%$ in 2010 to $86.30 \%$ in 2025 [20], but, if reduced by $168 \mathrm{~km}^{2}$, to attain a stable level, the agricultural water consumption should be decreased to at least half of what it is now. In this study, the suitable oasis area is far less than the actual area, which is a common issue in the Endorheic watershed oasis in Northwest China $[2,16,28]$. Reducing cropland in the oasis is the most direct and effective means, which is difficult to achieve. Specifically, individual croplands in the Dunhuang Oasis should be reduced to preserve the ecological environment. However, several reasons highlight the difficulty of this solution. (1) The reduction of croplands will harm the economic interests of farmers and subsequently decrease their quality of life. Thus, the possibility of criminal problems due to poverty should be considered. (2) The reduction of croplands is not in line with the Chinese policy of farmland protection. Hence, only on the basis of maintaining water-saving irrigation, reducing domestic water consumption, improving industrial water consumption efficiency, forbidding sprawl inside and outside the oasis, and increasing the amount of water allocated to the oasis from the water-transfer project, can the stability of the oasis be improved and the sustainable development of the regional economy and ecology be maintained.

\section{Conclusions}

This study analyzed the stability of the Dunhuang Oasis against the background of planting structure changes during the 1987-2015 period. Our main findings and recommendation are as follows:

1. From 1987 to 2015, the oasis irrigation district area expanded internally and externally, and, at the same time, the planting structure underwent a marked transformation, from food crops to cash crops to orchards. In the Dunhuang Oasis, the structure of croplands might be quickly and flexibly changed according to economic perspective and visions and policy reforms

2. In the Dunhuang Oasis, agricultural water consumption is mainly for food crops, cash crops, and orchards. From 1987 to 2015, food crop water consumption decreased sharply by $1.334 \times 10^{8} \mathrm{~m}^{3}$, cash crop water consumption (cotton) first increased by $2.374 \times 10^{8} \mathrm{~m}^{3}$ and then decreased substantially, and grape water consumption was closely related to that of cotton, which increased slowly in 2010 before rising rapidly.

3. The Dunhuang Oasis was at a stable level in 1987 and 1990 but gradually declined until it reached a dangerously unstable level in 2010. Meanwhile, serious ecological problems emerged one after the other. Against the background of water-saving measures and the water-transfer project, the stable level of the oasis increased to a metastable level of 0.22 in 2015.

4. The oasis irrigation district should be reduced by at least $168 \mathrm{~km}^{2}$ to reach a suitable scale. However, this goal does not facilitate the improvement of the living standards of farmers and is not in line with the Chinese policy of farmland protection. Hence, the most practical way at present is to increase allocated water resources from the water-transfer project to the oasis irrigation district. 
Author Contributions: X.Z. and Q.W. conceived and designed the experiments. X.Z. and Y.Z. performed the experiments and analyzed the data. J.Q. provided remote sensing image of 2010 and 2015. X.Z. and Q.W. wrote the paper. All authors have read and agreed to the published version of the manuscript.

Funding: This research was funded by the National Science Foundation of China, grant number: 41701321 and No. 41661105.

Conflicts of Interest: The authors declare no conflict of interest.

\section{References}

1. Li, X.; Cheng, G.; Ge, Y.; Li, H.; Han, F.; Hu, X.; Tian, W.; Tian, Y.; Pan, X.; Nian, Y.; et al. Hydrological Cycle in the Heihe River Basin and Its Implication for Water Resource Management in Endorheic Basins. J. Geophys. Res. Atmos. 2018, 123, 890-914. [CrossRef]

2. Ling, H.; Xu, H.; Fu, J.; Fan, Z.; Xu, X. Suitable oasis scale in a typical continental river basin in an arid region of China: A case study of the Manas River Basin. Quat. Int. 2013, 286, 116-125. [CrossRef]

3. Wang, Z.; Ficklin, D.L.; Zhang, Y.; Zhang, M. Impact of climate change on streamflow in the arid Shiyang River Basin of northwest China. Hydrol. Process. 2012, 26, 2733-2744. [CrossRef]

4. Kang, S.; Su, X.; Tong, L.; Zhang, J.; Zhang, L. A warning from an ancient oasis: Intensive human activities are leading to potential ecological and social catastrophe. Int. J. Sustain. Dev. World Ecol. 2008, 15, 440-447. [CrossRef]

5. De Fraiture, C.; Molden, D.; Wichelns, D. Investing in water for food, ecosystems, and livelihoods: An overview of the comprehensive assessment of water management in agriculture. Agric. Water Manag. 2010, 97, 495-501. [CrossRef]

6. Cheng, G.; Li, X.; Zhao, W.; Xu, Z.; Feng, Q.; Xiao, S.; Xiao, H. Integrated study of the water-ecosystem-economy in the Heihe River Basin. Natl. Sci. Rev. 2014, 1, 413-428. [CrossRef]

7. Custodio, E.; Andreu-Rodes, J.M.; Aragón, R.; Estrela, T.; Ferrer, J.; García-Aróstegui, J.L.; Manzano, M.; Rodríguez-Hernández, L.; Sahuquillo, A.; del Villar, A. Groundwater intensive use and mining in south-eastern peninsular Spain: Hydrogeological, economic and social aspects. Sci. Total Environ. 2016, 559, 302-316. [CrossRef]

8. Micklin, P.P. Desiccation of the Aral Sea: A water management disaster in the Soviet Union. Science 1988, 241, 1170-1176. [CrossRef]

9. Klein, I.; Dietz, A.J.; Gessner, U.; Galayeva, A.; Myrzakhmetov, A.; Kuenzer, C. Evaluation of seasonal water body extents in Central Asia over the past 27 years derived from medium-resolution remote sensing data. Int. J. Appl. Earth Obs. Geoinf. 2014, 26, 335-349. [CrossRef]

10. Stone, R. Saving Iran's Great Salt Lake; American Association for the Advancement of Science: Washington, DC, USA, 2015; Volume 349, pp. 1044-1047.

11. Tourian, M.; Elmi, O.; Chen, Q.; Devaraju, B.; Roohi, S.; Sneeuw, N. A spaceborne multisensor approach to monitor the desiccation of Lake Urmia in Iran. Remote Sens. Environ. 2015, 156, 349-360. [CrossRef]

12. Su, X.; Li, J.; Singh, V.P. Optimal allocation of agricultural water resources based on virtual water subdivision in Shiyang River Basin. Water Resour. Manag. 2014, 28, 2243-2257. [CrossRef]

13. Ling, H.; Xu, H.; Liu, X. Suitable scale of oasis in Keriya River Basin, Xinjiang. Adv. Water Sci. 2012, 23, 563-568.

14. Chen, Y.; Chen, Z. Analysis of oasis evolution and suitable development scale for arid regions: A case study of the Tarim River Basin. Chin. J. Eco Agric. 2013, 21, 134-140.

15. Hu, S.; Song, Y.; Tian, C.; Li, Y.; Li, X.; Chen, X. Suitale scale of Weigan River plain oasis. Sci. China Ser. D Earth Sci. 2006, 36, 51-57.

16. Hao, L.; Su, X.; Singh, V.P.; Zhang, L.; Zhang, G. Suitable oasis and cultivated land scales in arid regions based on ecological health. Ecol. Ind. 2019, 102, 33-42. [CrossRef]

17. Tang, Q. Water resources and oasis construction in Tarim Basin. Nat. Resour. 1989, 6, 28-34. [CrossRef]

18. Wang, Z.; Wang, H.; Lei, Z. Stability analysis of oasis in arid region. J. Hydraul. Eng. 2002, 5, 26-30.

19. Li, X.; Yang, D.; Xia, F. Analysis of the water footprint of suburban planting in arid lands and determination of suitable farmland scale: A case study of urumqi. Acta Ecol. Sin. 2015, 35, 2860-2869.

20. Zhang, X.; Jin, X.; Bai, X.; Jiang, Y.; He, C. Impacts of water resource planning on regional water consumption pattern: A case study in Dunhuang Oasis, China. J. Arid Land 2019, 11, 713-728. [CrossRef] 
21. Water Resource Department of Gansu Province. Comprehensive Planning of Rational Use of Water Resource and Protection of Ecosystem Services in the Dunhuang Region; Gansu People's Publishing House Press: Lanzhou, China, 2011.

22. Dunhuang National Economic Statistics Yearbook (1985-2015); Bureau of Statistics of The City of Dunhuang: Dunhuang, China, 2015.

23. Janssen, L.L.; Van der Wel, F.J. Accuracy assessment of satellite derived land-cover data: A review. Photogram. Eng. Remote Sens. 1994, 60, 419-426.

24. Allen, R.G.; Pereira, L.S.; Raes, D.; Smith, M. Crop Evapotranspiration-Guidelines for Computing Crop Water Requirements; FAO Irrigation and Drainage Paper 56; FAO: Rome, Italy, 1998.

25. Land and Water Development Division of Food and Agricultural Organization (FAO). 2019. Available online: http://www.fao.org/fileadmin/user_upload/faowater/Applications/CRW8.ZIP (accessed on 7 November 2019).

26. Industry Water Use Quota of Gansu Province; Water Resources Department of Gansu Province: Lanzhou, China, 2005.

27. Zhang, X.; Zhang, L.; He, C.; Li, J.; Jiang, Y.; Ma, L. Quantifying the impacts of land use/land cover change on groundwater depletion in Northwestern China-A case study of the Dunhuang oasis. Agric. Water Manag. 2014, 146, 270-279. [CrossRef]

28. Guo, H.; Ling, H.; Xu, H.; Guo, B. Study of suitable oasis scales based on water resource availability in an arid region of China: A case study of Hotan River Basin. Environ. Earth Sci. 2016, 75, 984. [CrossRef]

(C) 2020 by the authors. Licensee MDPI, Basel, Switzerland. This article is an open access article distributed under the terms and conditions of the Creative Commons Attribution (CC BY) license (http://creativecommons.org/licenses/by/4.0/). 